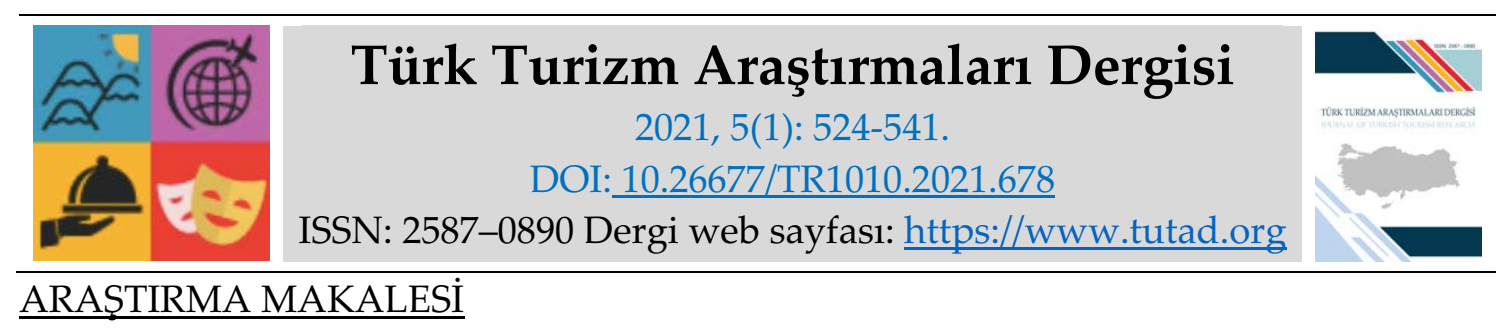

\title{
Somut Olmayan Kültürel Miras Unsuru Olarak Pamukçu Beldesi Oyunları*
}

Arş. Gör. Dr. Sultan Nazmiye KILIÇ, Balıkesir Üniversitesi, Turizm Fakültesi, Balıkesir, e-posta: sultan.kilic@balikesir.edu.tr

ORCID: https://orcid.org/0000-0003-0560-0622

Arş. Gör. Hasret ULUSOY, Balıkesir Üniversitesi, Turizm Fakültesi, Balıkesir, e-posta: hasretulusoy@balikesir.edu.tr

ORCID: https://orcid.org/0000-0003-1633-6804

Prof. Dr. Cevdet AVCIKURT, Balıkesir Üniversitesi, Turizm Fakültesi, Balıkesir, e-posta: avcikurt@balikesir.edu.tr

ORCID: https://orcid.org/0000-0002-9169-9763

$\ddot{O} z$

Somut olmayan kültürel miras unsurlarından biri olan ve geçmişi insanlık tarihi kadar eskilere dayanan yöresel halk oyunları hem kültürü besleyen hem de kültürden beslenen önemli bir olgudur. Bunun yanı sıra, halk oyunları toplum tarafından kabul gören ve kuşaktan kuşağa aktarımı sağlanan somut olmayan kültürel mirasın bir parçasıdır ve günümüzde halen Anadolu'nun birçok köşesinde yaşatılmaya devam etmektedir. Pamukçu Beldesi Oyunları da Balıkesir il envanterinde yer alan ve korunarak yaşatılması için uğraş verilen somut olmayan kültürel miras unsurlarından biridir. Bu doğrultuda, araştırmanın amacı Balıkesir ili Pamukçu Beldesi Oyunlarına dikkat çekerek farkındalığın arttırılmasına ve böylece gelecek kuşaklara aktarılmasına katkı sağlamaktır. Balıkesir Pamukçu yöresi halk oyunlarının gelecek kuşaklara aktarılmasında oyunu oynayan veya öğreten kişilerin görüşleri alınmış ve mevcut durum yansıtılmaya çalışılmıştır. Nitel araştırma desenlerinden durum çalışması deseni kullanılmış, görüşme tekniği ile Pamukçu Beldesi Oyunları hakkında detaylı bilgiler edinilmiştir. Araştırmada, oyunun gelecek nesillere aktarımı konusunda hassas davranıldığı, oyunların devam ettirildiği ve geçmişten alınıp geleceğe taşınması gerektiği fikrinin paylaşıldığı sonucuna ulaşılmıştır.

**Bu çalışma, 24-28 Nisan 2019 tarihleri arasında Muğla-Marmaris'te düzenlenen III. Uluslararası Turizm ve Kültürel Miras Kongresi'nde sözlü olarak sunulan bildirinin yeniden düzenlenmesi ile oluşturulmuştur.

Anahtar Kelimeler: Halk Oyunları, Somut Olmayan Kültürel Miras, Balıkesir, Pamukçu.

Makale Gönderme Tarihi: 04.01.2021

Makale Kabul Tarihi: 12.03 .2021

\section{Önerilen Atıf:}

Kılıç, S. N., Ulusoy, H. ve Avcıkurt, C. (2021). Somut Olmayan Kültürel Miras Unsuru Olarak Pamukçu Beldesi Oyunları, Türk Turizm Araştırmaları Dergisi, 5(1): 524-541.

(C) 2021 Türk Turizm Araştırmaları Dergisi. 


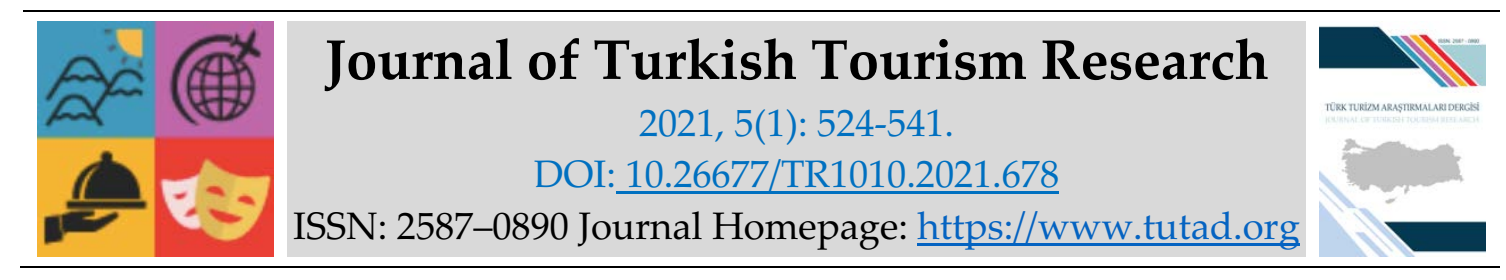

\title{
RESEARCH PAPER
}

\section{The Folk Dances of Pamukçu Town as An Element of Intangible Cultural Heritage}

Dr. Sultan Nazmiye KILIÇ, Balıkesir University, Faculty of Tourism, Balıkesir, e-mail: sultan.kilic@balikesir.edu.tr ORCID: https://orcid.org/0000-0003-0560-0622

Research Assistant Hasret ULUSOY, Balıkesir University, Faculty of Tourism, Balıkesir, e-mail: hasretulusoy@balikesir.edu.tr ORCID: https://orcid.org/0000-0003-1633-6804

Prof. Dr. Cevdet AVCIKURT, Balıkesir University, Faculty of Tourism, Balıkesir, e-mail: avcikurt@balikesir.edu.tr ORCID: https://orcid.org/0000-0002-9169-9763

\begin{abstract}
Folk dance, as being one of the elements of intangible cultural heritage and basing on a very old background as human history, is a significant phenomenon that both nourishes culture and is nourished by culture. In addition, folk dance is a part of an intangible cultural heritage that is accepted and intergenerationally transmitted by the society and kept alive in many parts of Anatolia. The Pamukçu Town Folk Dance is one of the intangible cultural heritage elements located in the Balikesir province inventory and is being tried to be preserved and kept alive. In this direction, the aim of the study is contributing to the increase of awareness and thus transferring to future generations by drawing attention to the Pamukçu Town Folk Dance of the province of Balikesir. The opinions of the people, who perform or teach the dance, were received and it is tried to reflect the current situation in transferring the folk dances of Balıkesir Pamukçu region to the next generations. One of the qualitative research designs, case study design was used. Detailed information about Pamukçu Town Folk Dance has been obtained by using interview technique. In the research, it was reached to conclusion that the dance was treated sensitively about the transfer to future generations, and the idea of carrying it from past to future was shared.
\end{abstract}

Keywords: Folk Dances, Intangible Cultural Heritage, Balıkesir, Pamukçu.

Received: 04.01.2021

Accepted: 12.03.2021

Suggested Citation:

Kılıç, S. N., Ulusoy, H. and Avcıkurt, C. (2021). The Folk Dances of Pamukçu Town as An Element of Intangible Cultural Heritage, Journal of Turkish Tourism Research, 5(1): 524-541.

(C) 2021 Türk Turizm Araştırmaları Dergisi. 


\section{Gíriş}

Farklı unsulardan oluşan bir birleşim olan kültür, toplumların farklılıklarından doğan renkleri yansıtmaktadır. Kültürü oluşturan bu unsurlardan biri halk danslarıdır. Diğer birçok kültürel unsur gibi halk dansları da küreselleşmenin etkisiyle günümüzde kaybolmakta veya ilk halinden uzaklaşarak günümüze uyarlanmaktadır.

Günümüzde kültürler, festival ve yarışma gibi yeni mekanlarda yaşamını sürdürmektedir (Aydın, 2017: 295). Bu nedenle, halk danslarının tarihi gelişimi incelenirken kişilerin ve kurumların yanı sıra festivallerin ve yarışmaların da ele alınması gerekir. Çünkü, festival ve yarışmalarla birlikte halk dansları en parlak dönemini yaşamıştır (Ötken ve Kızmaz, 2014: 940). Ancak, kültürü ifade etme gereksinimi oyunları meydana getiren asıl unsur (Yüksel, 2010: 1087) olmasına rağmen ticarileşme nedeniyle halk oyunlarında tek tipleşme yaşanmaktadır ve bulunduğu sosyal mekândan ayrılan oyunlar otantikliğini yitirmektedir (Altun, 2019: 1). Bunun yanı sıra, halk oyunlarının sahneye aktarılmasıyla karşılaşılan bazı sorunlar bulunmaktadır. Örneğin; halk oyunları sahneye aktarıldığında yeni bir kalıba sokulmaktadır ve yarışmalar halk oyunlarının değer kaybetmesine sebep olabilmektedir (Özarslan, 1999: 62).

Kültürel unsurların korunmasını ve farkındalığın artırılmasını amaçlayan çeşitli projeler ve programlar yürütülmektedir. En önemli çalışmalardan biri Birleşmiş Milletler Eğitim, Bilim ve Kültür Örgütü (UNESCO) tarafından yapılmaktadır. Bunun yanı sıra örgütsel veya bireysel boyutta çeşitli çalışmalar da bulunmaktadır. Bilimsel çalışmalarda somut olmayan kültürel mirasın daha fazla yer alması, bu unsurların korunmasını ve gelecek kuşaklara aktarılmasını destekleyebilmekte ve günümüzde nasıl bir durumda olduğunun anlaşılmasına yardımcı olmaktadır. Gerek küreselleşme gibi etkenler nedeniyle yaşanan değişimlerin gerekse bu çalışmaların sonuçları, kültürel unsurlara ve dolayısıyla bu unsurların günümüzdeki taşıyıcılarına veya uygulayıcılarına çoğu zaman doğrudan yansımaktadır. Bu nedenle, mirasın sahibi olan kişilerin görüşlerinin alınması somut olmayan kültürel mirasın günümüzdeki durumuna 1şık tutacaktır. Bu doğrultuda, araştırmanın amacı somut olmayan kültürel miras unsuru olarak Balıkesir ili Pamukçu Beldesi Oyunlarına dikkat çekerek farkındalığın arttırılmasına ve bu oyunların gelecek kuşaklara aktarılmasına katkı sağlamaktır. Araştırmada Balıkesir Pamukçu yöresi halk oyunlarının gelecek kuşaklara aktarılmasında oyunu oynayan veya öğreten kişilerin görüşleri alınmış ve mevcut durum yansıtılmaya çalışılmıştır.

\section{KAVRAMSAL ÇERÇEVE}

Folklor, "halk bilim" anlamına gelen bir terimdir. İngilizce folk (halk) ve lore (bilim) kelimelerinin birleşimiyle oluşmuştur. Halkların kültürlerini oluşturmalarını, inançlarını, geleneklerini, müziklerini, oyunlarını, türkülerini, el sanatlarını ve bunun gibi birçok özelliğini inceleyen bilimdir. Foklor kavramı 1846 yılında W. John Thomas öne sürmüştür (Örnek, 1971: 88). Türkçede halk bilimi veya halk bilgisi olarak kullanımları bulunsa da en yaygın kullanılış şekli folklor kelimesidir (Örnek, 2015: 585).

Folklorun önemli bir parçası olan halk oyunlarının Türkiye'de Rıza Tevfik (Bölükbaşı) tarafından hazırlanan "Raks" isimli makale ile 1900 yılında başladığı kabul edilir. İlk uygulaması ise 1925 yılında Selim Sırrı Tarcan tarafından zeybek oyununun figürlerinden faydalanılarak oluşturulan ve öğrencilere öğretilen oyundur. Bu oyun daha sonra Atatürk'ün huzurunda da oynanmıştır. 1926 yılında ilk derleme çalışması yapılmıs, 1927 yılında ise ilk dernek kurulmuştur. 1929 yılında çeşitli illerdeki halk oyunları filme alınmıştır. 1932'de Halk Evlerinin kurulmasıyla birlikte halk oyunlarıyla ilgili uğraşlar daha sistemli hale getirilmiştir. Gruplar kurulmuş ve derlemeler hazırlanmıştır. 1935 yılında ilk uluslararası halk oyunları festivali olan "Beylerbeyi Balkan 
Festivali" gerçekleştirilmiştir. 1955 yılında "Türk Halk Oyunlarını Yaşatma ve Yayma Tesisi" kurulmuş, 1961 yılında bu alanda seminer düzenlenmiş ve 1968 yılında oyunlar filme kaydedilmiştir. Sonraki senelerde çeşitli üniversitelerde halk oyunları bölümleri kurulmuştur. 1974 yılında ise "Devlet Halk Dansları Topluluğu" oluşturulmuştur. Sonraki yıllarda farklı devlet kurumları tarafından çeşitli yarışmalar düzenlenmiştir (Çakır, 2000). 90'lı yıllarda çeşitli özel dans gruplarının ortaya çıkmasıyla birlikte Türkiye'de halk dansları sektörleşmeye başlamıştır (Ötken ve Kızmaz, 2014: 930).

Somut olmayan kültürel miras "Sözlü anlatımlar, sözlü gelenekler, gösteri sanatları, toplumsal uygulamalar, ritüel ve festivaller, halk bilgisi, evren ve doğa ile ilgili uygulamalar, el sanatları geleneği gibi kültürel ürünleri ve üretim süreçlerini ifade eden kavramdır." şeklinde tanımlanmaktadır (T.C. Kültür ve Turizm Bakanlığı, 2019d). Tablo 1'de Balıkesir iline ait somut olmayan kültürel miras unsur listesi yer almaktadır. Bu tablodan da anlaşılabileceği gibi Balıkesir il envanterinde 12 adet somut olmayan kültürel miras unsuru yer almaktadır. İl envanterinde yer alan bu 12 unsurdan 9'unun ulusal envantere de alındığı görülmektedir. Pamukçu Beldesi Erkek Oyunları da il envanterinde yer alan oyunlardan biridir (T.C. Kültür ve Turizm Bakanlığı, 2019c).

Tablo 1. Somut Olmayan Kültürel Miras Unsur Listesi (Balıkesir)

\begin{tabular}{|c|l|l|c|}
\hline S.N & Unsurun Adı & Ulusal Envanterdeki Adı & Ulusal Envanter No \\
\hline 1 & $\begin{array}{l}\text { Çepni ve Tahtacılarda Kamberlik } \\
\text { Geleneği }\end{array}$ & Aşıklık Geleneği & 10.003 \\
\hline 2 & Barana Geleneği & $\begin{array}{l}\text { Barana, Sıra Gecesi, Yaren vb. } \\
\text { Geleneksel Sohbet Toplantıları }\end{array}$ & 10.006 \\
\hline 3 & Yağcıbedir Halıları & Halı Dokuma Geleneği & 10.035 \\
\hline 4 & Köy Hayırları & Hayır Geleneği & 10.037 \\
\hline 5 & Keçe Yapımı & Keçecilik El Sanatları Geleneği & 10.041 \\
\hline 6 & Zili/Sili & Kilim Dokuma Geleneği & 10.042 \\
\hline 7 & Gönen Ĭğne Oyası & Oya Sanatı & 10.051 \\
\hline 8 & Deve Oyunu & Deve Oyunu & 10.073 \\
\hline 9 & Tülü Kabak & Kız Kaçırma Oyunu & 10.084 \\
\hline 10 & Şayak-Aba Dokuma & & İl Envanteri \\
\hline 11 & Sarıbeyler Seferberlik Çöreği & & İ Envanteri \\
\hline 12 & Pamukçu Beldesi Erkek Oyunları & & ̇̇l Envanteri \\
\hline
\end{tabular}

Kaynak: (T.C. Kültür ve Turizm Bakanlığı, 2019c)

Balıkesir iline bağlı Pamukçu Beldesi, merkeze 15 km uzaklıktadır (Balıkesir Valiliği İl Kültür ve Turizm Müdürlüğü, 2009: 3). Pamukçu'da düğünlerde, bayramlarda ve diğer eğlencelerde "İkili Güvende", "Toplu Güvende" ve "Bengi" oynanmaktadır. "İkili güvende" iki kişi tarafından oynanan hareketli bir oyundur. İki tarafın savaşçıları arasında en güçlü iki kişinin savaşını simgelemektedir. Oyun öncesinde müzikle birlikte "Aldırma" adı verilen kısa süren bir gezinti yapılmaktadır. "Oyuna Alma" ile oyun başlamaktadır. Oyun, dönme ve çökme hareketlerinden oluşmaktadır ve temposu hızlıdır. Erkek oyunlarında zurna, bağlama, klarnet ve davul çalgı olarak kullanılmaktadır (Balıkesir Büyükşehir Belediyesi, 2019).

Pamukçu beldesi "Bengi" adı verilen zeybek ile ünlüdür (T.C. Kültür ve Turizm Bakanlı̆̆ı, 2019b). "Balıkesir Bengisi"nin diğer adı "Tetik Oyunu"dur. Sadece Balıkesir ilinin Pamukçu beldesinde oynanan "Bengi" harman zamanında dügünler ve muhabbetler başlayınca köy 
meydanında oynanmaktadır. Geçmişte, düşmanı yendikten sonra oynanan bir oyun olduğu düşünülmektedir (T.C. Kültür ve Turizm Bakanlığı, 2019a). "Bengi", Balıkesir ve çevresinin yerel dansıdır. Zeybek danslarıyla ortak özelliklere sahiptir (Mirzaoğlu, 2004: 1). "Pamukçu Bengisi", Pamukçu Beldesi'nin bir parçasıdır. Sadece Pamukçu beldesinde oynanan oyun, düğünlerin, Erfene Sohbetleri'nin ve Akpınar Eğlenceleri'nin baş oyunudur. Belde, Pamukçu Bengisi ve "oyunu adeta şiir gibi oynayan Bengicilerin" sayesinde Türkiye'de ve dünyada tanıtılmıştır. "Bengi", "sonu olmayan, ebedi" anlamına gelmektedir. Kelimenin tarihinin İslamiyet öncesi Göktürkler dönemine kadar gittiği düşünülmektedir. Örneğin, Orhun Kitabeleri, Göktürkler tarafından "Bengü Taş" olarak isimlendirilmiştir. Ayrıca, bir rivayete göre Türkler Orta Asya'dan Anadolu'ya gelirken savaşlarda ölen düşmanlarının başında "Bengi!" narası atıldığı, bunun bir yiğitlik göstergesi ve gelenek olduğu düşünülmektedir (Balıkesir Valiliği, 1999: 115). Bir başka deyişle, kelimenin kaynağının savaşlar olduğu düşünülmektedir. Oyunun çıkış havası kendine özgüdür. Asıl havadan ayrıdır, gezenti şeklindedir. 8-10-12-15 veya daha fazla kişi ile oynanabilmektedir. Beş figür bulunan "Bengi", daire şeklinde soldan sağa doğru icra edilmektedir (Balıkesir Büyükşehir Belediyesi, 2019). Kıyafet ise şu şekildedir (T.C. Kültür ve Turizm Bakanlı̆̆ı, 2019a):

"Dizler dışarda kalmak üzere kısa, bol ve kıvrıml dizlik, ayaklarda tozluk belde dolalı uzun kuşaklar ve kuşakta tütün keseleri ile yüz çevresi vardır. Kuşağın üzerinde sarı veya kara deriden silahlık ve beli üstten dolayan bir kayıs bulunur. Bu silahlık gözlüdür. İlk gözde yatağan, ikincide tabanca, üçüncü gözde de hançer yer almıştır. Efe sırtına el tezgahında dokunmuş ipekten sarı veya gök mavisi renginde gömlek giyer. Kolları uzun, yırtmaçlı saçaklıdır. Meydanda dolaşırken bu saçaklar kartal kanatlarl gibi süzülür. Efeye azamet ve heybet verdirirler. Mintan üzerinde kolsuz yelek, omuzdan bele kadar düşen kanatl cepken giyerler. Yelek ceplerinden gümüş kordon sarkar. Boyundan göğüse doğru üç köşeli meşin sallanır. Bu meşin göğ̈̈s kalkanının ufalmış bir örneğgidir. Başa da trablus ve ipekten bağlama sarilır."

Oyun, Pamukçu erkekleri tarafından oynanmakta ve babadan oğula aktarılmaktadır. "Pamukçu Bengisi"nin oyuncuları çeşitli illerdeki gösterilere katılmışlardır. "Bengi", "hayır" adı verilen ziyafetlerden sonra oynanmaktadır. Pamukçu'da düzenlenen sohbet toplantılarında küçükler, büyükleri seyrederek oyunu öğrenmektedir (T.C. Kültür ve Turizm Bakanlığı, 2019b). Ayrıca, Pamukçu'da bayramlarda ve düğünlerde "Söbbet" denilen kış sohbetlerinde deve oyunu gibi çeşitli seyirlik oyunlar oynanmaktadır ve sohbetler "Bengi" ile başlatılmaktadır (Duymaz ve Şahin, 2010: 174-178).

Atatürk, 24 Haziran 1934 tarihinde İran Şahı Rıza Pehlevi ile birlikte Balıkesir'e geldiğinde Pamukçu Bengisi ile karşılanmıştır. Kaynaklar, Tevfik Güngörmüş, Ahmet Atagün ve Necip Şengül'ün oyun ekibi içerisinde yer aldığını, Atatürk'ün oyunu çok beğendiğini ve birkaç defa oynattığını belirtmektedir. Ardından, Atatürk tarafından verilen emirle ekip gezinin devamına katılmış ve Çanakkale'ye kadar gitmiştir. Aynı yıl İstanbul'da Ali Hikmet Paşa'nın davetlisi olarak Küçük Çiftlik Parkı'nda gösteri yapan ekip, sonrasında Atatürk tarafından Dolmabahçe Sarayı'na davet edilmiştir. 1957 yılında Pamukçu Halk Oyunları Derneği kurulmuştur. İlk yurtdışı seyahati, 1958 yılında Kıbrıs'ta 19 Mayıs Bayramı kutlamalarına katılmak üzere gerçekleştirilmiştir. Aynı yıl, Nis ve Kan Festivali'ne, Brüksel'de gerçekleştirilen "Türk Gecesi"ne ve İtalya'da düzenlenen askeri bayrama katılmışlardır. 4-14 Kasım 1968 tarihleri arasında Monako'da gerçekleştirilen "Dünya Turizm Cemiyetleri"nin 70. kuruluş yılı kutlamalarında yer almışlardır. 1973 yılında ise Tunus'ta Akdeniz Oyunları'nda Türkiye'yi temsil etmişlerdir. Yerli ve yabancı birçok devlet başkanının huzurunda oynayan ekip, gösterileriyle takdir kazanmıştır (Balıkesir Valiliği, 1999: 115). "Bengi" oyununun tanıtılabilmesi için 1975 yılında Pamukçu'da kurulan dernek günümüzde halen faaliyetlerini sürdürmektedir (Balıkesir Büyükşehir Belediyesi, 2019). 
Halk oyunlarını ve müziklerini inceleyen betimleyici nitelikteki derleme çalışmalarının sayısında 1950'li ve 1960'lı yıllarda artış yaşanmıştır (Kurt Kemaloğlu, 2012: 2). Ancak, halk oyunları ile ilgili literatürde yeterli çalışma bulunmamaktadır. Bu alanda hazırlanan sözlü tarih çalışmaları da yetersizdir (Ötken ve Kızmaz, 2014: 929). Ancak yine de halk oyunlarını farklı yönlerden inceleyen araştırmalar gerçekleştirilmiştir. Bu araştırmalar, inceleme amaçları açısından farklılık göstermektedir. Aydın (1996) bibliyografya incelemesi, Önder (2001) folklor sosyolojisi, Mirzaoğlu (2004: 1) Zeybek dansları ile "Bengi" arasındaki ilişki, Karabaşa (2007) mevcut durum, Agat (2002) ile Kaya, Çoksevim ve Paktaş (2010) kıyafetler, Uslu (2013) üniversite öğrencilerine etkisi, Okdan (2014) çalgı takımları, Okdan (2016) yapısal analiz, Ayhan (2012) ve Ay (2019) ise turizm açısından değerlendirmiştir. Çavuş ve Baki (2020: 279) tarafından gerçekleştirilen çalışmada halk oyunları festivalinin yerel halkın sosyalleşmesine yardımcı olduğu ve turizmin gelişimine katkı sağladığı sonucuna ulaşılmıştır. Folklorik zenginliklerin turizm amaçlı kullanımı yaygınlaşmıştır. Böylece, somut olmayan kültürel değerler yaşatılmakta, gelecek kuşaklara aktarılmakta ve kültür turizmi geliştirilmektedir (Serbest, 2020: 758). Bu nedenle, halk kültürü ve turizm arasında yadsınamaz bir bağ bulunmaktadır (Artun, 2002). Ancak, Ar (2015) tarafından gerçekleştirilen araştırma, turist rehberlerinin halk oyunu ve orta oyun gibi gösteri sanatlarını turistlerin an az ilgisini çeken somut olmayan kültürel miras unsurları olarak algıladığı sonucuna ulaşmıştır (Ar, 2015: 90). Bu nedenle, halk oyunlarının turizme yeterli katkı sağlayabilmesi için doğru planlama yapılması gerektiği düşünülmektedir (Ayhan, 2012: 1).

Ayrıca, araştırmalarda farklı yörelerin halk oyunları inceleme konusu olmuştur. Örneğin, Sümbül (1995) Adana halk oyunlarını, Önder (2001) Sivas halaylarını, Agat (2002) Kırım Türkleri halk oyunlarını, Karabaşa (2007) Burdur ili halk oyunlarını, Kaya, Çoksevim ve Paktaş (2010) Tokat yöresi halk oyunlarını, Yüksel (2010) Kastamonu halk oyunu olan Sepetçioğlu'nu, Koçkar ve Koçkar (2015) Karaçay-Malkarlıların halk danslarını, Okdan (2016) İzmir'in kadın Zeybek oyunlarını ve Özdemir (2020) Giresun "Çandır Tüfek Oyunu"nu incelemiştir. Ötken'e göre (2010: 50) geleneksel uygulamalarda dini inançlar gereği kadın ve erkek oyunları ayrı alanlarda yapılmıştır. Kadın ve erkek oyunları farklı alanlarda oynandığı için kadın oyunlarında enstrümanlar farklılaşmıştır. Örneğin, kadın oyunlarında davul ve zurna gibi enstrümanlar yerine kaşık gibi ev aletleri kullanılmıştır (Altun, 2019: 4).

Bazı çalışmalarda doğrudan öğrenci ve eğiticilerin görüşlerinin anlaşılması amaçlanmıştır. Çelebi (1991) tarafından gerçekleştirilen araştırmada eğiticilerin ve öğrencilerin algıları incelenmiştir. Ötken ve Kızmaz (2014: 929-930) ise İstanbul'da halk danslarını icra edenlerle görüşmeler yapmıştır. Hacıcaferoğlu, Bozkuş ve Kızılkaya (2014: 36) halk oyunlarına başlama sebeplerini araştırmıştır. Araştırmada halk oyunlarına başlamada en önemli sebeplerden birinin "halk oyunlarına olan sevgi" olduğu görülmüştür. Doğan'ın (2011: 232-233) araştırma sonuçları ise halk oyunlarının sosyal bütünleşmeye olan faydasını desteklemektedir.

Halk oyunlarına yönelik literatür yoğun olarak, derleme çalışmaları, kısa yazılar ve haberlerden oluşmaktadır (Kurt Kemaloğlu, 2012: 1). Ancak son yıllarda, farklı halk oyunlarının incelendiği çalışmalar dikkat çekmektedir. Örneğin, Özdemir (2020: 161) Pamukçu Oyunları gibi savaş kaynaklı olduğu düşünülen ve "Oğuzların çeviklik ve savaşçılı özelliğinin bir hikâyesi" olduğu ileri sürülen Çandır Tüfek Oyunu'nu incelemiştir. Pamukçu Beldesi oyunları da araştırmalarda ele alınan halk oyunlarından biri olmuştur. Bu bağlamda, Mirzaoğlu (2004) ve Atlı'nın (2015) araştırmaları öne çıkmaktadır. Mirzaoğlu (2004) "Balıkesir Bengisi”ni incelemiştir. Atlı (2015) Pamukçu Erfene Toplantıları'nı incelediği çalışmasında Pamukçu halk oyunlarına da yer vermiştir. Şahin (2009) ise çalışmasında Pamukçu'da görülen tokmak çeşidini resimlendirmiştir. Ancak, ilgili literatürde Pamukçu halk oyunlarını somut olmayan kültürel miras açısından inceleyen bir araştırmaya rastlanmamıştır. Bu nedenle, bu araştırmada Pamukçu halk oyunları; oyunun özellikleri, mevcut durumu ve geleceğe aktarılması gibi yönlerden incelenecektir. 
Biyolojik ve kültürel (sosyal) ihtiyaçları karşılayan halk oyunlarının iletişim, eğitim ve eğlence gibi işlevleri bulunmaktadır. Ayrıca oyunlar, toplumsal değerlerin oluşumuna ve devamlılığına yardımcı olmaktadır (Sümbül, 1997: 2-6). 50'li yıllarda halk oyunlarıyla ilgili derneklerin, özel alanlarda ve kamusal alanlarda düzenlediği faaliyetlerin sayısında artış yaşanmıştır. Ardından halk oyunları, değişim ve dönüşüm sürecine girmiştir. Özellikle, 70'li ve 80'li yıllarda otantiklikle ilgili tartışmalar belirginleşmiştir (Kurt Kemaloğlu, 2012: 6-7). Çünkü halk oyunları, zamanla sahne sanatlarına evrilmiştir ve bu dönüşüm sürecinde, halk oyunları kimi zaman sahnelenme nedeniyle orijinalinden uzaklaşıp yerel halktan soyutlanmıştır. Ancak, otantik ve sahnelenen halk oyunlarının farklılığının anlaşılması ve birinin diğerinden üstün tutulmaması gerektiği düşünülmektedir (Altun, 2019: 1). Bunun yanı sıra, folkloru bir kalıp olarak görmek yerine; yaşayan, toplumun ihtiyaçlarını karşılayan, canlı bir oluşum olarak düşünmek gerekmektedir (Artun, 2002). Sonuç olarak, ilgili literatürde yer alan çalışmaların otantiklik tartışması, sürdürülebilirlik ve derlemeler gibi belli başlıklar altında toplandığı görülmüştür (Kurt Kemaloğlu, 2012).

\section{YÖNTEM}

Çalışmada derinlemesine bilgi edinilebilmesi için nitel araştırma yöntemi tercih edilmiş ve durum çalışması deseni kullanılmıştır. Durum çalışmalarında tek veya az sayıdaki durum yakından ve detaylı olarak incelenmektedir (Yin, 2017: 4). Bu doğrultuda, görüşülen kaynak kişilerden elde edilen veriler, ilgili literatür ve araştırma soruları göz önünde bulundurularak başlıklar halinde değerlendirilmiştir. Katılımcılara kartopu örnekleme yöntemi ile ulaşılmıştır. Önce mahalle muhtarına ulaşılmış, ardından diğer katılımcıların isimleri ve iletişim bilgileri alınmıştır. Çalışma grubu bu oyunu bizzat oynamış olan kişilerden ve öğreticilerden oluşmaktadır. Katılımcılar 28-80 yaş arasındadır. Katılımcıların 2'si emekli, 1'i serbest meslek çalışanı, 1'i memur, 1'i sosyolog, 2'si öğretmen ve 1'i öğrencidir. Ayrıca, 7'si erkek ve 1'i kadındır. Toplam sekiz katılımcı ile görüşme yapılarak bilgiler elde edilmiştir. Tablo 2' de çalışma grubuna ilişkin bilgiler yer almaktadır.

Tablo 2. Çalışma Grubuna İlişkin Bilgiler

\begin{tabular}{|l|c|c|c|c|}
\cline { 2 - 5 } \multicolumn{1}{c|}{} & Görüşme Tarihi & Yaş & Meslek & Cinsiyet \\
\hline K1 & 12.04 .2019 & 80 & Emekli & Erkek \\
\hline K2 & 12.04 .2019 & 74 & Emekli & Erkek \\
\hline K3 & 15.04 .2019 & 50 & Serbest Meslek & Erkek \\
\hline K4 & 15.04 .2019 & 50 & Memur & Erkek \\
\hline K5 & 15.04 .2019 & 41 & Sosyolog & Kadın \\
\hline K6 & 16.04 .2019 & 79 & Emekli Öğgretmen & Erkek \\
\hline K7 & 17.04 .2019 & 64 & Öğretmen & Erkek \\
\hline K8 & 17.04 .2019 & 28 & Ö̆ğrenci & Erkek \\
\hline
\end{tabular}

Araştırmada verileri elde edebilmek için yarı yapılandırılmış görüşme formu kullanılmıştır. Görüşmeler, 12-17 Nisan 2019 tarihleri arasında gerçekleştirilmiştir. Görüşme öncesinde katılımcılara araştırmanın amacı ve içeriği hakkında bilgi verilmiştir ve ses kaydı için izin alınmıştır. Araştırma deseni doğrultusuna "çoklu kanıt kaynaklar" (görüşme ve fotoğraflar) kullanılmıştır (Yin, 2017: 10). Bu kapsamda, görüşme sırasında çeşitli notlar alınmış ve belgeler toplanmıştır. K1'den temin edilen ve Şekil 1, Şekil 2 ve Şekil 3'te sunulan fotoğraflara katılımcının 
izniyle araştırmada yer verilmiştir. Görüşmeler bizzat araştırmacılar tarafından gerçekleştirilmiştir. Katılım tamamen gönüllük esasına dayandırılmıştır. Çalışmada katılımcıların yaş ve meslek gibi demografik bilgileri alındıktan sonra, 4 ana soru ve 5 alt soru yöneltilmiştir. Ayrıca gerektiğinde konu ile ilgili daha detaylı bilgi alabilmek için ek sorular da sorulmuştur. Katılımcılara yöneltilen sorular şunlardır: Oyunların isimleri nelerdir? Oyunların tarihçesi hakkında bilgi verir misiniz? Oyunlar ne zaman oynanıyor? Oyunları anlatır mısınız? Oyunlarda yer alan hareketler ve anlamları nelerdir? Kimden öğrendiniz? Öğrettiğiniz biri var mı? Gelecek kuşaklara öğretilmesi konusunda ne düşünüyorsunuz? Oyunlar sizin için ne ifade ediyor?

Araştırma sonucunda elde edilen ses kayıtları araştırmacılar tarafından deşifre edilmiştir. Verilerin değerlendirilebilmesi amacıyla betimsel analiz gerçekleştirilmiş ve bilgiler temalar altında incelenmiştir (Yıldırım ve Şimşek, 2011: 224). Bu doğrultuda, öncelikle çerçeve oluşturulmuş ve veriler bu tematik çerçeveye göre işlenmiştir. Ardından, bulgular tanımlanmış ve yorumlanmıştır (Yıldırım ve Şimşek, 2016: 240). Temaların belirlenmesinde araştırma sorularından faydalanılmıştır.

Araştırmada inandırıcılık kapsamında farklı araştırmalarda da göz önünde bulundurulan bazı metotlar kullanılmıştır (Yılmaz, 2017; Yılmaz ve Özdemir, 2017; Arman vd., 2018; Yılmaz vd., 2018; Erdem vd., 2018; Ulusoy Yıldırım, Kılıç ve Avcıkurt, 2020). Bu metotlar; verilerin bizzat araştırmacılar tarafından elde edilmesi (Kozak, 2014), araştırma sürecinin ayrıntılı olarak aktarılması (Elo vd., 2014), en az 2 araştırmacının analiz sürecine dahil olması (Hall ve Valentin, 2005), gerekli görülen yerlerde doğrudan alıntılara yer verilmesi (Hsieh ve Shannon, 2005) ve son olarak analizde tartışma ve uzlaşma yönteminin kullanılmasıdır (Graneheim ve Lundman, 2004).

\title{
BULGULAR
}

$\mathrm{Bu}$ bölümde araştırma sorularına alınan yanıtlar doğrultusunda elde edilen verilere tema başlıkları altında yer verilmiştir. Görüşmeler deşifre edilmiş ve K1, K4 ve K8'in oyunlara ilişkin aktardığı görseller incelenmiştir. Katılımcılar oyunla ilgili hatırlarını anlatırken oldukça heyecanlı bir tavır sergilemişlerdir. K1 ve K2 bu oyunu oynamış olan beldedeki en yaşlı kişilerdir.

\section{Oyunlar ve Özelliklerine İlişkin Bulgular}

Oyun beldenin bir simgesi durumundadır. Belediye binasının önünde iki efenin heykeli bulunmaktadır (Bkz. Şekil 1). Heykelin altında yer alan mâni şu şekildedir:

\author{
"Balıkesir Ovası'nın bağı var bostanı var \\ Pamukçu Efe'sinin ünü var destanı var \\ Aslan Efe'm çete olmuş \\ Ata'dan fermani var. \\ $* * *$ \\ Davul vursun, klarnet çalsın \\ Çifte kazan kaynasin \\ Mor kadife sirma cepken \\ Efelerim oynasin."
}




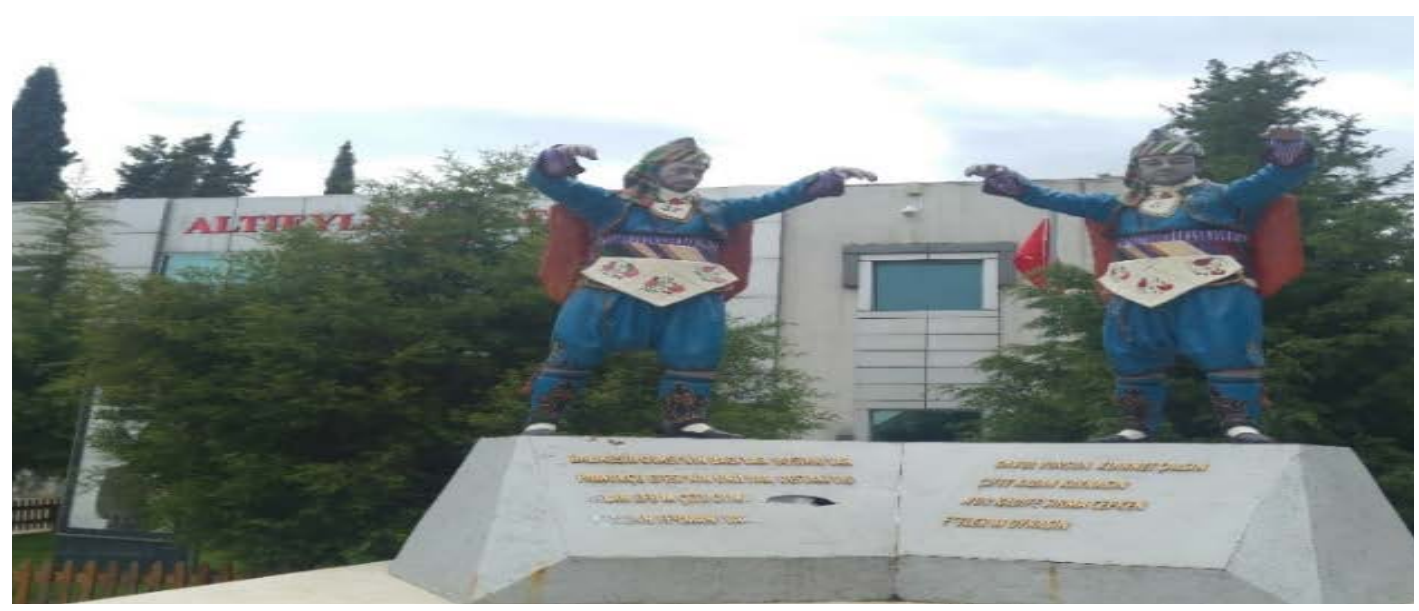

Şekil 1: Belediye Binasının Önünde Bulunan İki Efe Heykeli ve Altında Yer Alan Mâni

Kaynak: Yazarlar Tarafından Fotoğraflanmıştır.

Katılımcılar Pamukçu Erkek Oyunları altında dört oyundan bahsetmiştir. Bunlar; "İkili Güvende", "Toplu Güvende", "Bengi” ve "Pamukçu Karşılaması”dır. Ancak, eski kuşak sıralı oynanan üç oyundan bahsederken yeni kuşak "Pamukçu Karşılaması"nı da ekleyerek 4 oyundan bahsetmektedir. K8 oyunların belli bir sıralamasının olmadığını, 4 oyunun birbirinden farklı ve benzer yanları olduğunu dile getirmiştir.

"İkili Güvende": İki kişi tarafından oynanmaktadır ve başlangıç oyunudur. Bu oyun bittiğinde "Toplu Güvende" ye geçilmektedir (K3). Bu oyun, diğer illerde solo yani tek kişi oynanmaktadır (K8). "İkili güvende" de bir erkek en güvendiği kişiyi oyuna çağırarak karşılıklı oynamaktadır (K4). Bu oyun, kendine güvenenler tarafından oynanabilmekte ve güvende kelimesi "güven" $i$ ifade etmektedir (K7).

"Toplu Güvende": Sekiz kişi tarafından oynanmaktadır. Ardından "Bengi”ye geçilmektedir (K3). Bu oyun, daire şeklinde toplu bir biçimde oynanmaktadır (K8).

"Bengi": Bu oyun da sekiz kişi tarafından oynanmaktadır (K3). "Bengi", "sonu olmayan" (K3, K4, $\mathrm{K} 5)$, "sonsuzluk", "ebedi" (K4, K5), "ölümsüzlük" (K8) anlamlarına gelmektedir.

"Pamukçu Karşılaması": Düğüne gelen insanları karşılamak için oynanmaktadır (K4, K5, K7, K8). Bu oyun, kişilerin kendilerini sevdiklerine göstermek için oynadıkları bir oyundur (K7). Oyun önceleri gelin karşılamalarında oynanmış daha sonra ise protokol karşılamalarında oynanmaya devam edilmiştir (K8).

\section{Oyunların Tarihçesine İlişkin Bulgular}

Oyunun tarihi, eski zamanlarda yaşayan Türklere dayanmaktadır. Buna göre; “İkili güvende” iki ordunun en yaverlerinin ortaya çıkıp birbirlerine meydan okumalarını anlatmaktadır. Önce bu iki kişi dövüşmektedir. Ardından ordular savaşmaktadır. Bu savaş, "Toplu Güvende” oyununda yansıtılmaktadır. "Bengi" oyunu ise kazanılan zaferden sonra sevinç gösterilerini anlatmaktadır (K6).

"Bengi"nin çıkışı Orta Asya'ya, göçlere dayanmaktadır (K3) ve "Bengi" ismi oyuna Atatürk tarafından verilmiştir (K1). 1933 yılında Atatürk'ün Balıkesir'e gelişinde onun önünde bu oyun oynanmıştır ve Atatürk bu oyunu çok beğenerek ekibi Çanakkale, İzmir ve Ankara' ya çağırmıştır 
(K7, K6). Orta Asya'dan oynanarak gelen bir oyundur ancak Pamukçu'ya nasıl mâl olduğu bilinmemektedir (K8).

\section{Oyunların Oynandığı Zamanlara İlişkin Bulgular}

Oyun; düğünlerde, yarışmalarda ve etkinliklerde oynanmaktadır (K1, K2, K3, K8). Oyunların yurtiçinde ve yurt dışında icra edilmesi bakanlıklar, belediyeler ve okullar tarafından desteklenmektedir. Katılımcıların masrafları bu kurumlar tarafından karşılanmaktadır. Katılımcılar bu şekilde İtalya, Tunus, Kıbrıs gibi ülkeleri gezmiş; Kırşehir, Erzurum, Gümüşhane, Samsun gibi şehirlerde yarışmalara katılıp madalyalar almışlardır. Oyun ayrıca İstanbul'da yapılan Balıkesir gecelerinde de oynanmaktadır.

\section{Oyunun İcra Edilişi ile İlgili Bulgular}

Oyun oynayan kişilere "Efe" adı verilmektedir (K1). Oyunlar kabiliyete bağlıdır. Oyun sırasında "efe" gibi yürünmelidir. Ayrıca, "efe"lerin uygun davranışlar sergilemesi (örneğin, içki içip sarhoş olmaması gibi) beklenmektedir (K2). Oyunlar en az 6 kişiyle ve eşli oynanmaktadır (K1). Oyunlar hızlı ve çok hareketlidir; bu nedenle hata yapılma olasılığı oldukça yüksektir. Bu hızla birlikte eş zamanlı hareket etmek zordur (K1, K2, K4, K5). Öğrenmesi kolay olan oyunun çabuk unutulduğu belirtilmiştir. Örneğin Ankara'dan gelen bir kişinin beldede 10 gün kaldığı ancak döndüğünde oyunu unutarak tekrar beldeye geldiği K1 tarafından dile getirilmiştir. Benzer şekilde efelerden biri Ankara'ya oyun öğretmeye gitmiş, döndükten bir ay sonra tekrar çağırılmıştır.

Oyunlar oynanırken giyilen kostüm, kep, yazma, cepken, çevre (yazmadan kuşak), sivri burun yuvarlak topuklu ayakkabıdan oluşmaktadır (K1). Ayrıca, katılımcılardan alınan bilgilere göre oyun müziğinde davul ve girnata yer almaktadır. Oyunda kullanılan enstrümanlar oyunun kapalı veya açık mekânda oynanmasına göre değişmektedir. Açık alanlarda davul ve gırnata (klarnet) kullanılmakta; evde ise darbuka ve zilli maşa kullanılmaktadır. Son dönemlerde bağlama da eklenmiştir.

Oyundaki naraların savaşta kazanılan zafer naraları olduğu belirtilmiştir (K3). "Bengi", savaş sonrası zafer kutlamasıdır (K4, K7). Oyunda yer alan hareketlerden biri de kılıç sallama hareketidir. "Bengi oyunu", savaş sonrası düşmanın kafası etrafında oynanmasını anlatmaktadır (K4). Oyunların oynanışı ve oynayan efelerle ilgili olarak K1 kişisel arşivinden Şekil 2, Şekil 3 ve Şekil 4'de fotoğraflar sunmuştur.

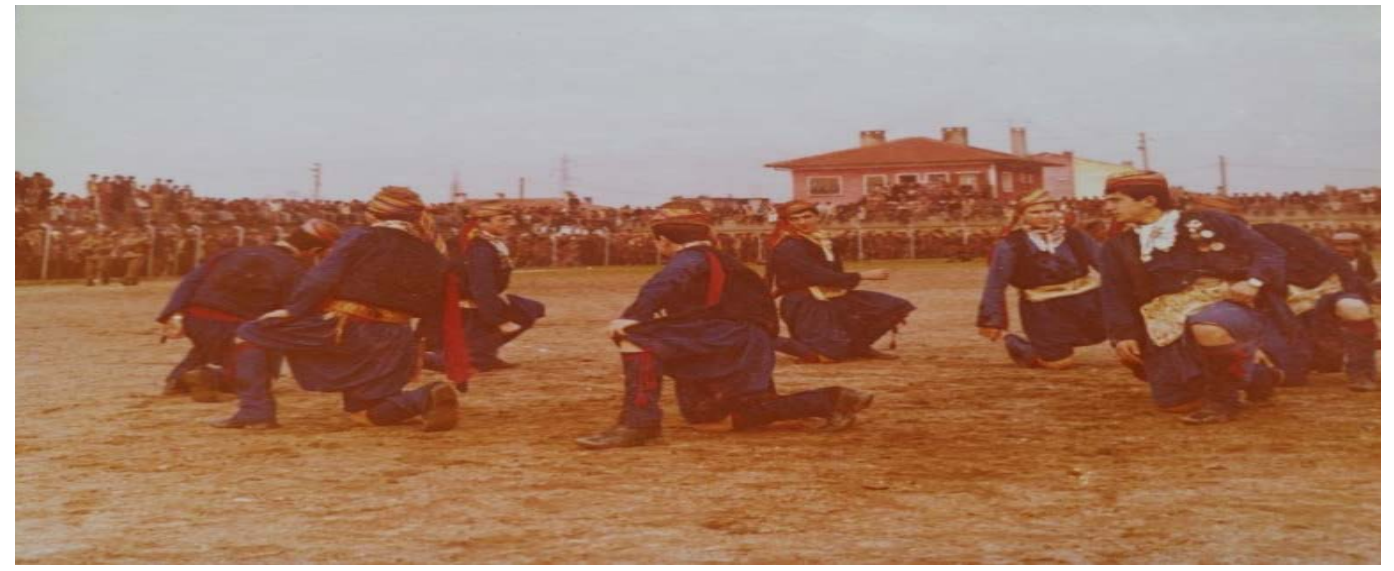

Şekil 2: K1'in Kişisel Arşivinden Bir Fotoğraf 


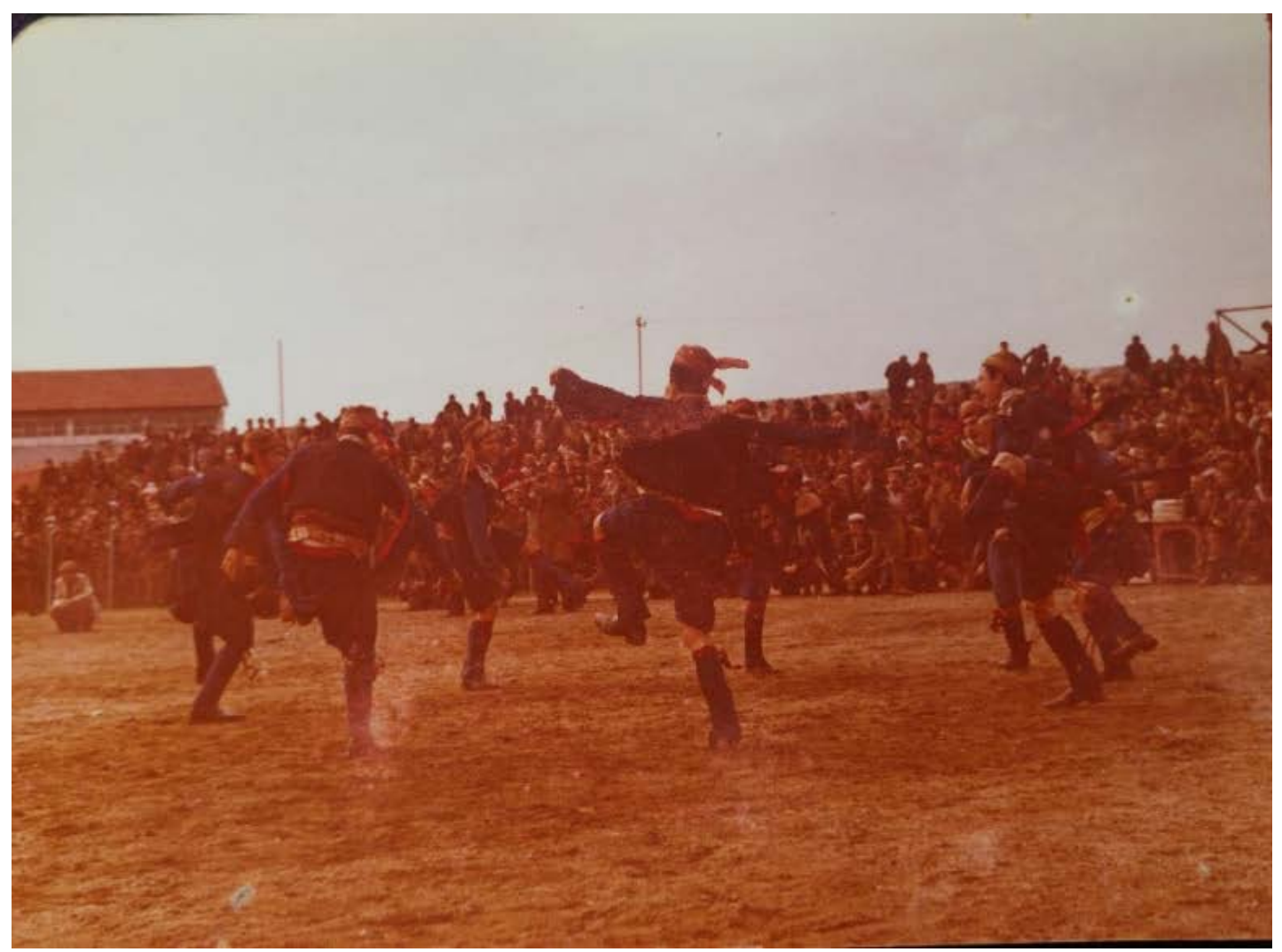

Şekil 3: K1'in Kişisel Arşivinden Bir Fotoğraf

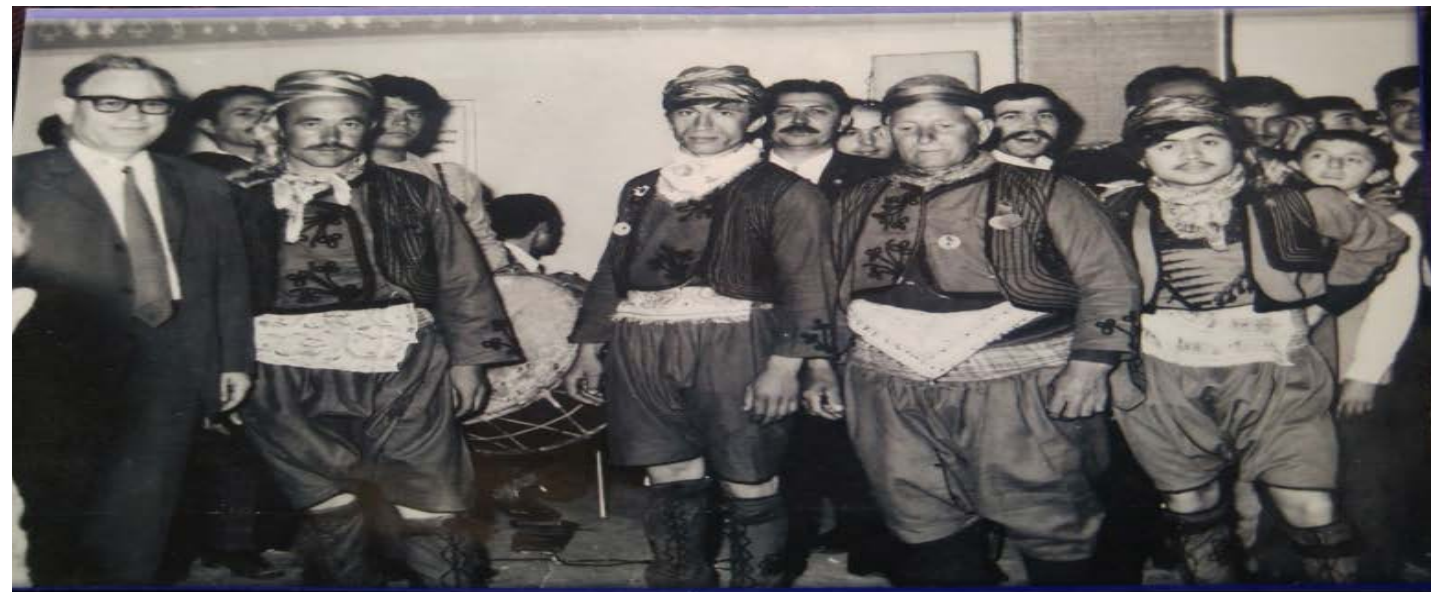

Şekil 4: K1'in Kişisel Arşivinden Bir Fotoğraf

\section{Oyunların Kimden Öğrenildiğine İlişkin Bulgular}

Oyun halihazırda o dönemin gençleri tarafından yapılan toplantılarda oynandığı için onlardan öğrenilmiştir. Her hafta düzenlenen "Erfene Geceleri” adı verilen bu sohbet toplantılarında (K4, K5, K7) "dayıbaşı" denilen ve oyunu bilen kişi yer almaktadır. Oyunu öğreten kişiye ise "oyuncubaşı" adı verilmektedir. Katılımcıların oyunu kimden öğrendiğine ilişkin bulgular aşağıda yer almaktadır:

- K1, oyunu 1974 yılından bu yana oynadığını ve öğretmen olan babasının da bu oyunu oynadığını belirtmiştir. 
- $\mathrm{K} 2$, sohbet toplantılarında öğrendiğini dile getirmiştir.

- K3, 1982' den beri oynadığını ve dört kuşak öncesinden öğrendiğini ifade etmiştir.

- K4, ilkokuldayken büyüklere bakarak öğrenmeye çalıştığını ifade etmiştir. ("Onlar oynuyor, biz niye oynamayalım."). Oyuna ilk olarak "İkili güvende" ile başlamıştır ve 1979 yılından bu yana oyunu oynadığını belirtmiştir.

- K5, diğer katılımcilardan farklı olarak Dursunbey'lidir. Ancak, Pamukçu oyunlarıyla yakından ilgilenmektedir. 1997 yılında başlamış, 1998 yılından bu yana ekip hazırlamaya başlamıştır.

- $\mathrm{K} 6$, oyunu yaşlılardan öğrenmiştir.

- K7, oyunları dedesinden öğrendiğini ifade etmiştir. Ayrıca, oyunların düğünlerde, Akpınar eğlencelerinde ve Erfene Sohbet Toplantıları'nda (Erfene Geceleri) köyün gençleri tarafından oynandığını dile getirmiştir.

- $\mathrm{K} 8$, oyunları $\mathrm{K} 4$ 'ten öğrendiğini belirtmiştir.

\section{Oyunların Gelecek Kuşaklara Öğretilmesine İlişkin Bulgular}

Oyunun Devam Ettirilmesine Yönelik Çabalar: K1'den elde edilen bilgiler oyunun beldede ileri gelen bir aile tarafından sahiplendiğini ve yaşatılmaya çalışıldığını göstermiştir. K6 oyunların tekrar hayat bulmasını sağlayan kişidir. 1979'da Pamukçu' ya gitmiştir ve orada yıllarca öğretmen ve okul müdürü olarak çalışmıştır. K6 Pamukçu'ya gittiğinde oyunun ölmek üzere olduğu ve oyunu bilen 5-6 kişinin kaldığını belirlemiştir. Ardından ekip kurarak oyunu yeniden canlandırmıştır. Ayrıca, K6 oyun Atatürk'ün huzurunda oynandığı için ve dünya çapında derece aldığı için bu işe emek verdiğini ifade etmiştir. Çalıştığ 1 dönemde okullarda seçmeli dersler olduğunu ve haftada 2-4 saat sürdüğünü anlatmıştır. Okulda, Milli Oyun dersi, seçmeli ders olarak okutulmaya başlanmıştır. Başlarda çocukları ve efeleri kontrol etmenin ve oyun düzeninin kurulmasının zor olduğunu ifade etmiştir. Bu nedenle, oyunu öğretebilecek kişiyi arayıp bulduğunu ve bu kişiyle birlikte oyunun oynanabilmeye başlandığını belirtmiştir. Oyun es ile başladığı için bu kişi olmadan öğrenilmesi zor olmuştur.

K7 Balıkesir il merkezinde bir ortaöğretim kurumunda öğretmenlik yapmıştır. Pamukçu Beldesinde bu oyunu öğrenen öğrencilerin bu ortaöğretim kurumuna gelmesini sağlayarak oyunları burada çalıştırmaya devam etmiştir. K7 ayrıca bu alanda bir STK'nın başkanlığını yapmaktadır. Bu oyunların gelecek kuşaklara aktarılması için mücadeleye devam ettiğini belirtmiş ve bu oyunlarla ilgili bir kitap çıkarmak istediğini dile getirmiştir. K4'ü yetiştirdiğini ve onun bu işlerle yakından ilgilendiğini ifade etmiştir.

K8 şu an bu oyunu öğretmek için okullara gittiğini belirtmiştir. Okullardan ve halk eğitim merkezlerinden taleplerin geldiğini ifade etmiştir. Halk eğitim merkezinin kursu ile öğretici belgesi almıştır. Halk oyunlarında nitelikli oyuncu yetiştirilebilmesi için küçük yaşta alınıp bütün kültürü ile birlikte öğretilmesi gerektiğini ifade etmiştir. K8 “Oyuna biz sahip çıktık, ölene kadar da devam edeceğiz. Öğretmeye çalışacağız ama şu an öyle bir yere geldi ki jenerasyon tabletten kafasını kaldırmıyor. Bizden sonra ölür mü bilmiyorum." diyerek kültürün sürdürülebilirliğine yönelik kaygısını dile getirmiştir.

Sivil Toplum Kuruluşları: Günümüzde bir spor kulübü oyunu yaşatmaya devam etmektedir. K4 ve K5 de dernek kurucularındandır. K4 derneğinin amacının "çocuklara oyunları doğru bir şekilde aktarmak" olduğunu belirtmiştir. Bu oyunla ilgili dernek 2006 yılında kurulmuştur. Dernek oyun derlemeleri yapmaktadır. Öğrencileri yarışmalara hazırlamaktadır. Ayrıca bölge halkı ile görüşerek kostüm derlemeleri hazırlanmıştır. Oyun, 1997 yılından bu yana 1000'in üzerinde öğrenciye öğretilmiştir (K4, K5). Ayrıca, katılımcılardan alınan bilgilere göre 
günümüzde oyun, ortaokul olarak açlan liseye dönüştürülen okulda öğrencilere aktarılmaktadır. 8-10 öğrenciye sürekli eğitim verildiği belirtilmiştir.

Oyunun Orijinalinin Bozulması: K2 oyunun son zamanlarda değiştirilerek kadınların da oyuna dahil edildiğini ve oyunun orijinal halinin değiştirildiğini belirtmiştir. K4 ve K5 oyunu oynamış olan yaşlıların günümüzdeki koreografilerde kadınların da bu oyunları oynamasına tepki gösterdiğini ancak zamanla ödüller ve dereceler alındıkça durumun kabullenildiği ifade etmişlerdir. Ayrıca K4 ve K5 koreografilerin oyunun orijinaline zarar verdiğini belirtmişlerdir. K8 yarışma kültürü öldürdüğü için yarışmalara pek sıcak bakmadığını belirtmiştir. K3 “işi şova döndürdüler." ifadesini kullanarak aslının değiştirildiğini belirtmiştir.

Oyunların Kaybolması: K4 ve K5 sıralaması değiştirildiğinde müziğin ritmi dahi bozulacağı için Türkiye genelinde bozulmadan orijinalini koruduğunu belirtmişlerdir. K8 Türkiye Halk Oyunları Federasyonu'nun Türkiye'de özünü kaybetmemiş iki oyun bulunduğunu bunların da Pamukçu'ya ait olan "İkili Güvende" ve "Bengi" oyunları olduğunu belirtmiştir.

Beldede ayrıca kadınlar tarafından kaşıkla oynanan "Hambaraltı" oyunu bulunmaktadır (K1). Ancak günümüzde bu oyunun devam ettirilmediği öğrenilmiştir. Benzer şekilde, K3, geçmişte bazı seyirlik oyunların olduğunu ancak günümüze kadar ulaşmadığını belirtmiştir. K7 oyunları köydeki her gencin 20 yıl önce oynayabildiğini ifade edilmiştir.

\section{Oyunların Katılımcılar İçin İfade Ettiği Anlama İlişkin Bulgular}

K4 oyunun kendisi için "zevk" ve "hobi" olduğunu dile getirmiştir. "Çocuklara öğretirken yorgunluğumu, stresimi atıyorum" ifadesini kullanmıştır. K5 için oyunun anlamı "mutluluk"tur. K5 kendisini "aktarıcı olarak" gördügünü ifade etmiştir. Geçmişten alıp geleceğe aktarmanın para ile ölçülemez olduğunu belirtmiştir.

K7 bu oyunların kültüre katkıda bulunduğunu ifade etmiştir. Bu oyunları oynamaya 1972'de başlamıştır ve oyunların kendisine çok şey kattığını, gönlünü zenginleştirdiğini, çevresini genişlettiğini ve toplum içine girmeyi öğrettiğini belirtmiştir.

K8 "Çok keyif alarak yaptığım için şu an hayatımın merkezinde. Yarışmalarda başarılı olmak adına çok uğraştık. Ancak bu yarışmaların kültürümüze zarar verdiğini fark ettik. ... Kendimiz bir şenlik düzenledik, halk oyunları, giyim, yemek gibi Pamukçu'nun bütün kültürünü kapsayan..." Bu şenlik "Pamukçu Bengi ve Gülgülü Şenliğì"dir. "Gülgülü", gülün gülü anlamına gelmektedir. Bu şenliklerde Pamukçu'nun kültürünün yalnızca halk oyunlarından ibaret olmadığı, müzik, yemek, giyim kuşamla birlikte tam anlamıyla anlatılmaya çalışıldığı ifade edilmiştir. K8 oyunun kültürünü yansıttığını ve bu yolla kendisini ifade edebildiğini belirtmiştir. Oyunun K3 için anlamı kültürü doğru bir şekilde ileri götürmek, doğru bir şekilde aktarmaktır. Son olarak K1“Oyun sayesinde gezdiğim yerleri paramla gezemem." ifadesiyle oyunların kişisel gelişimine katkısını aktarmıştır.

\section{TARTIŞMA, SONUÇ ve ÖNERILLER}

Geçmişten günümüze kuşaktan kuşağa aktarılan ve insanlık tarihi kadar eski olan kültür kavramı, toplumları var eden unsurlardan biridir. Geçmiş toplumların geleceğe bıraktıkları izlerden oluşan somut ve somut olmayan kültür varlıkları, gözlemleyenlerde ve deneyimleyenlerde hayranlık uyandırmaktadır. Günümüzde, halk oyunları gibi somut olmayan kültürel miras unsurlarının zamana yenik düşmemesi için çeşitli çalışmalar yapılmaktadır. Somut olmayan kültürel miras unsurlarının bilimsel çalışmalarla desteklenmesi, korunmasına ve gelecek nesillere aktarılmasına yardımcı olmaktadır. Bu doğrultuda çalışmada, Pamukçu Beldesi 
oyunlarının incelenmesi, mevcut durumunun ve gelecek kuşaklara aktarımının değerlendirilmesi amaçlanmıştır. Çalışmada oyunların isimlerine, özelliklerine, tarihçesine, öğrenilişine, gelecek kuşaklara aktarılışına ve oyunu oynayanlar için ifade ettiği anlama ilişkin bilgiler değerlendirilmiştir. Çalışmada derinlemesine bilgi edinilebilmesi için nitel araştırma yöntemi tercih edilmiştir. Görüşülen kaynak kişilerden elde edilen veriler, ilgili literatür ve araştırma soruları göz önünde bulundurularak başlıklar halinde değerlendirilmiştir. Katılımcılara kartopu örnekleme yöntemi ile ulaşılmıştır. Önce mahalle muhtarına ulaşılmış, ardından diğer katılımcıların isimleri ve iletişim bilgileri alınmıştır.

Destinasyonların ayırt edici özelliklere sahip olması tanınırlığının ve çekiciliğinin artmasına yardımcı olmaktadır. Bu çalışma sonucunda elde edilen bilgiler, oyunların Pamukçu'ya bir kimlik kazandırdığını göstermiştir. Belediye binasının önündeki efe heykelleri bu durumu destekler niteliktedir. Kültürü ifade etme gereksinimi oyunları meydana getiren asıl unsurdur (Yüksel, 2010: 1087). Ancak oyunlar Pamukçu'da geçmişte yaşamın bir parçası durumundayken kültürel alışkanlıkların küreselleşme ya da teknoloji kaynaklı değişimi nedeniyle günümüzde çoğu zaman etkinliklerde ve yarışmalarda sergilenmektedir. Oyununu oynayan efelerin ifadelerinden, oyunun kendilerine ve hayata bakış açlarını geliştirmelerine çok fazla katkısının olduğu anlaşılmıştır. Ayrıca, katılımcıların oyunun gelecek nesillere aktarımı konusunda hassas davrandıkları ve bunun mücadelesini vermekte oldukları anlaşılmıştır. Bu kapsamda, oyunların genel olarak katılımcılar tarafından devam ettirildiği ve geçmişten alınıp geleceğe taşınması gerektiği fikrini paylaştıkları anlaşılmıştır. Bir başka deyişle, katılımcıların oyunların yaşatılması ve geleceğe aktarılması için çeşitli uğraşları olduğu belirlenmiştir.

Ayrıca, oyunun orijinalinin yarışmalar nedeniyle bozulmaya başladığı anlaşılmıştır. Katılımcılar, özellikle oyunun orijinaliyle devam etmesi gerektiğini birçok defa vurgulamıştır. Orijinal haliyle sergilenmemesi, halk oyunlarının genel bir sorunudur çünkü günümüzde sahneye aktarılmaları nedeniyle; halk oyunları yeni bir kalıba sokulmaktadır ve yarışmalar halk oyunlarının değer kaybetmesine sebep olabilmektedir (Özarslan, 1999: 62). Ancak bu noktada, halk oyunlarının ekip dansı olmasından dolayı doğaçlama yapılamaması, sahnede karmaşık bir görüntü olmaması için tek tipleştirilmesi ve bu şekilde tek vücut görüntüsüyle seyircinin etkilenmeye çalışılması gibi konulardan da bahsedilmesi gerekmektedir (Altun, 2019: 6). Katılımcıların görüşleri doğrultusunda ortaya çıkarılan bir başka önemli sonuç, bölgeye ait diğer somut olmayan kültürel unsurların günümüzde yaşatılamaması nedeniyle yok olmaya başlamasıdır.

Katılımcılardan biri kitap hazırlama çabası içerisindedir. Buna karşın, yapılan görüşmeler esnasında yerel halkın eşit derecede mirasa sahip çıkmadığı ifade edilmiştir. Bu nedenle, kültürün korunması konusunda genel bir bilinç oluşturulması gerekmektedir.

Kültürün korunması ve aktarımı, yaşayan bireylerin o kültüre sahip çıkmasına bağlıdır. Bu durumun Pamukçu oyunlarında bir okul müdürünün çabalarıyla başladığı anlaşılmaktadır. Bu kişi oyunu bilenlere ulaşarak tekrar yaşatmaya çalışmıştır. Ayrıca, oyunlar yurtdışında ve Türkiye'nin farklı illerinde tanıtıldığı için kamu desteğinin de oyunların yaşatılmasında önemli olduğu görülmektedir. Günümüzde, kültürel mirasın korunması için oyunun özellikle gelecek kuşaklara aktarılmasında sivil toplum kuruluşlarının verdikleri desteklerin önemi anlaşılmıştır.

Kültürel miras unsuru olmasının yanı sıra halk oyunları, sosyal ve kültürel gelişim sağlayabilmekte ve toplumu birleştirici yönü ile ön plana çıkabilmektedir (Karacan Doğan ve Yetim, 2011: 45). Bu bağlamda halk oyunları devam ettirilmeli, ilgili tüm kurum ve kuruluşlar iş birliği içinde mirasa sahip çıkmak için çalışmalar yapmalıdır. Gelecek kuşakların ilgisinin azalması ise bu oyunlar için bir tehdit durumundadır. Bu nedenle, halk oyunlarının ve somut olmayan diğer mirasların okul müfredatlarında daha fazla yer alması faydalı olabilmektedir. $\mathrm{Bu}$ doğrultuda, il envanterine kayıtlı olan somut olmayan kültürel miras unsurları bölgesel olarak 
okullarda seçmeli ders şeklinde verilebilir. Böylece, öğrenciler önce kendi bölgelerinde bulunan kültürel miras unsurlarını tanıyabilmekte ve daha sonra ulusal envantere kayıtlı somut olmayan kültürel miras unsurlarına sahip çıkma bilinci kazanabilmektedir. Araştırmaya dahil olan katılımcıların halk oyunlarına yönelik görsel arşivinin olduğu gözlemlenmiştir. Bu doğrultuda miras bilinci kazandırılması adına yörede bir sergi açılabilir. Ayrıca, bu değerin turizme kazandırılması ve yerel yönetimin somut olmayan kültürel miras konusunda merkez ya da müze açması, çalışmaların sürdürülebilir olmasını sağlayabilir.

Ülke tanıtımında önemli rolü olan halk dansları turistik çekicilikler arasında yer almaktadır. Ancak turistik ilginin artırılması amacıyla dansların özünden farklı gösterimi doğru bulunmamaktadır (Ay, 2019: 103). Bir başka deyişle, turizme aktarılan halk oyunu gösterimlerinin kültürün özünden uzaklaşmaması gerektiği ve sergilenen halk oyunlarının gerçekçi olmasının turizm açısından olumlu sonuçlar sağlayabileceği düşünülmektedir (Ayhan, 2012:3-4). Bu nedenle, turizm sektöründe kültürün özüne zarar vermeden nasıl aktarım yapılacağı önemli bir sorudur. Halk oyunlarının turizmde daha doğru sunulabilmesi için bu alanda uzman kişilerin gösterilerin nasıl olması gerektiğine ilişkin seminerler ve örnek çalışmalar sunması faydalı olabilir. Ayrıca, kurslar ve eğitici kitaplar da sağlanabilir. Özellikle, halk kültürü müzeleri kültürün otantik örneklerinin saklanması ve geleceğe aktarımı açısından faydalı olabilir (Artun, 2002).

Bilimsel çalışmalarda somut olmayan kültürel mirasın daha fazla yer alması, bu unsurların korunmasını ve gelecek kuşaklara aktarılmasını destekleyebilmektedir. Bu doğrultuda, araştırmanın Balıkesir ili Pamukçu Beldesi Oyunlarına dikkat çekerek farkındalığın arttırılmasına ve böylece gelecek kuşaklara aktarılmasına katkı sağlayacağı, bilinç kazandıracağı düşünülmektedir. Bu nedenle, somut olmayan kültürel mirasın günümüzdeki temsilcilerinin görüşlerini değerlendiren çalışmaların sayısının artmasının faydalı olacağı düşünülmektedir. Kültürel unsurlara ilişkin özelliklerin "kulaktan dolma" bilgilerle sunulması tanıtımında doğru bilgi aktarımını engellemektedir (Artun, 2002). Çalışmada görüşme yapılan kişiler, oyunların tarihçesi hakkında başkalarından duydukları veya okudukları doğrultusunda bilgi vermiştir. Dolayısıyla, oyunların bilimsel bir tarihçesi ve hikayesi olması noktasında gelecekte yapılması planlanan çalışmalarda farklı paydaşlarla çalışılarak (konservatuar, tarih, folklor alanında bilim insanları) oyunların gerçek hikâyeleri ortaya konabilir.

\section{KAYNAKÇA}

Agat, S. (2002). Kırım Türkleri Halk Oyunları ve Geleneksel Giysileri, Yayımlanmamış Yüksek Lisans Tezi, İstanbul Teknik Üniversitesi Sosyal Bilimler Enstitüsü, İstanbul.

Altun, R. Ö. (2019). Türk Halk Oyunlarında Doğaçlama ve Kurgu İkilemi, Ahenk Müzikoloji Dergisi, (5): 1-14.

Ar, H. (2015). Somut Olmayan Kültürel Mirasin Korunmasinda Turist Rehberlerinin Rolü, Yayımlanmamış Yüksek Lisans Tezi, Balıkesir Üniversitesi Sosyal Bilimler Enstitüsü Turizm İşletmeciliği ve Otelcilik Anabilim Dalı, Balıkesir.

Arman, A., Erdem, Ö., and Ören, T. Ş. (2018). Investigation of Academic Staff in Gastronomy in Terms of Their Satisfaction Level and Adverse Experience, Journal of Tourism and Gastronomy Studies, 4(4): 644-661.

Artun, E. (2002). Türk Folklorunun Turizm Açısından Değerlendirilmesi, Folklor Halkbilim Dergisi, 5(50): 3-7. [Online] http://turkoloji.cu.edu.tr/HALKBILIM/7.php [Erişim Tarihi: 05.02.2021]. 
Atlı, S. (2015). Somut Olmayan Kültürel Mirasa Bir Örnek: Balıkesir Pamukçu Erfene Sohbet Toplantıları, Uluslararası Sosyal Araştırmalar Dergisi, 8(40): 7-25.

Ay, E. (2019). Halk Dansları Eğitmenlerinin Halk Danslarını Turizm Açısından Değerlendirmelerine İlişkin Nitel Bir Çalışma, Uluslararası Folklor Akademi Dergisi, 2(1): 103-120.

Aydın, A. (1996). Musiki Mecmuası ve Türk Folklor Araştırmaları Dergisinde Türk Halk Müziği ve Oyunları Hakkında Yazılmış Makalelerin Bibliyografya İncelemesi ve Sonuçları, Yayımlanmamış Sanatta Yeterlik Tezi, İstanbul Teknik Üniversitesi Sosyal Bilimler Enstitüsü, İstanbul.

Aydın, E. C. (2017). Halk Oyunları Temsilinde Kültürel Mekân İşlevi, Zeitschrift für die Welt der Türken/Journal of World of Turks, 9(2): 287-295.

Ayhan, A. (2012). Halk Oyunları Gösterilerinde Temsil Edilen Kültürün, Türkiye Kültür Turizmindeki Yansımaları. 1. Uluslararası Türk Halk Oyunları Kongresi, 10-12 Mayıs 2012, İnönü Üniversitesi/Malatya.

Balıkesir Büyükşehir Belediyesi (2019). Balıkesir Kent Portalı. [Online] http://www.balikesir.com.tr/tr/kent-kulturu/halk-oyunlari-ve-seyirlikler [Erişim Tarihi: 24.04.2019].

Balıkesir Valiliği (1999). Balıkesir. TŞOF Plaka Matbaa.

Balıkesir Valiliği İl Kültür ve Turizm Müdürlüğü. (2009). Balıkesir. [Online] https://balikesir.ktb.gov.tr/Eklenti/7877,balikesirtanitimbrosurupdf.pdf?0\&_tag1=4F21313A6A8 89930806324A7EB01EB6A48463259 [Erişim Tarihi: 12.02.2020].

Çakır, A. (2000). Atatürk Döneminden Günümüze Türk Halk Oyunları Üzerine Bir Değerlendirme, I. Uluslararası Atatürk ve Türk Halk Kültürü Sempozyumu Bildirileri [Online] https://ekitap.ktb.gov.tr/TR-78699/ataturk-doneminden-gunumuze-turk-halk-oyunlari-uzerine.html [Erişim Tarihi: 07.04.2020].

Çavuş, A., ve Baki, A. (2020). Yerel Halk Üzerindeki Sosyal Etkileri Bakımından Akçaabat Müzik ve Halk Oyunları Festivali, Atatürk Üniversitesi Sosyal Bilimler Enstitüsü Dergisi, 24(1): 279-289.

Çelebi, A. (1991). Türk Halk Oyunları Eğitici ve Öğrencilerinin Türk Halk Oyunlarını Nasıl Alg̨ladıklarına İlişkin Bir Araştırma (İzmir İli Örneği), Yayımlanmamış Yüksek Lisans Tezi, Selçuk Üniversitesi Sağlık Bilimleri Enstitüsü, Konya.

Doğan, P. K. (2011). Halk Oyunlarının Sosyal Bütünleşmeye Etkisi, Yayımlanmamış Doktora Tezi, Gazi Üniversitesi Sağlık Bilimleri Enstitüsü, Ankara.

Duymaz, A., ve Şahin, H. İ. (2010). Balıkesir ve Çevresinde Hayvan Benzetmecesine Bağlı Köy Seyirlik Oyunları, Balıkesir Üniversitesi Sosyal Bilimler Enstitüsü, 13(23): 171-185.

Elo, S., Kaariainen, M., Kanste, O., Pölkki, T., Utriainen, K., and Kyngas, H. (2014). Qualitative Content Analysis: A Focus on Trustworthiness, Sage Open, 4(1): 1-10.

Erdem, Ö., Mızrak, M. ve Kemer, A. K. (2018). Yöresel Yemeklerin Bölge Restoranlarında Kullanılma Durumu: Mengen Örneği, Uluslararası Türk Dünyası Turizm Araştırmaları Dergisi, 3(1): 44-61.

Graneheim, U. H. and Lundman, B. (2004). Qualitative Content Analysis in Nursing Research: Concepts, Procedures and Measures to Achieve Trustworthiness, Nurse Education Today, 24: 105112. 
Hacıcaferoğlu, S., Bozkuş, T., ve Kızılkaya, N. (2014). Türk Halk Oyunlarına Katılan Bireylerin Halk Oyunlarına Başlama Sebeplerinin İncelenmesi, Uluslararası Hakemli Beşeri ve Akademik Bilimler Dergisi, 3(7): 36-44.

Hall, C. M. and Valentin, A. (2005). Tourism Research Methods, (Editor) Ritchie, B., Burns, P. and Palmer, C.: In Content Analysis (pp. 191-209) Cambridge: CAB International.

Hsieh, H. and Shannon, S. E. (2005). Three Approaches to Qualitative Content Analysis, Qualitative Health Research, 15(9): 1277-1288.

Karabaşa, S. (2007). Burdur İli Halk Oyunlarının Günümüzdeki Durumu ve Düşündürdükleri, Milli Folklor, 19(74): 91-98.

Karacan Doğan, P. ve Yetim, A. A. (2011). Halk Oyunlarının Sosyal Bütünleşmeye Etkisi, Gazi Beden Eğitimi ve Spor Bilimleri Dergisi, 16(3): 27-48.

Kaya, M., Çoksevim, B., ve Paktaş, Y. (2010). Tokat Yöresi Halk Oyunları Kıyafetleri, Türk Kültürü ve Hacı Bektaş Veli Araştırma Dergisi, (56): 249-268.

Koçkar, M. T., ve Koçkar, R. (2015). Türkiye' de Yaşayan Karaçay-Malkarlıların Halk Dansları ve Müzik Gelenekleri, Motif Akademi Halkbilimi Dergisi, 8(16): 397-424.

Kozak, M. (2014). Bilimsel Araştırma: Tasarım, Yazım ve Yayım Teknikleri. Ankara: Detay Yayıncılık.

Kurt Kemaloğlu, B. (2012). Türkiye'de Halk Danslarını Sahneleme Politikaları: Söylemler ve Estetik Yaklaşımlar, Yayımlanmamış Doktora Tezi, Yıldız Teknik Üniversitesi Sosyal Bilimler Enstitüsü, İstanbul.

Mirzaoğlu, F. G. (2004). Bir Kahramanlık Dansı: Balıkesir Bengisi, Türkbilig, 7, 101-108.

Okdan, H. Y. (2014). Zeybek Oyunlarına Eşlik Eden Çalgı Takımları, Akademik Bakış Uluslararası Hakemli Sosyal Bilimler Dergisi, 45, 1-7.

Okdan, H. Y. (2016). İzmir İli Geleneksel Kadın Zeybek Oyunlarının Yapısal Analizi, International Journal of Human Sciences, 13(1): 332-347.

Önder, E. (2001). Folklor Sosyolojisi Açısından Sivas Halayları, Türklük Bilimi Araştırmaları, 10, 80-105.

Örnek, S. V. (1971). Etnoloji Sözlüğü. Ankara: Ankara Üniversitesi Dil ve Tarih Coğrafya Fakültesi Yayınları: 200. [Online] http://sedatveyisornek.humanity.ankara.edu.tr/files/2014/12/ORNEKEtnoloji_Sozlugu.pdf [Erişim Tarihi: 17.02.2020].

Örnek, S. V. (2015). Türk Halkbiliminin Sorunları, Folklor/Edebiyat, 21(82): 585-590.

Ötken, N. (2010). Geleneksel ve Yeni Uygulamalar Üzerinden Halk Oyunlarının Sahnelenmesinde Kadın ve Bedenin İmgeleri, Yedi, Dokuz Eylül Üniversitesi Güzel Sanatlar Fakültesi Dergisi, 4, 49-54.

Ötken, N. C., ve Kızmaz, İ. (2014). Sözlü Tarih Denemesi: 1960-1980 Yılları Arasında İstanbul'da Halk Dansları, Uluslararası Sosyal Araştırmalar Dergisi, 7(34): 929-947.

Özarslan, M. (1999). Doğal Ortamdan Sahneye Geçiş Sürecinde Halk Oyunları Üzerine Düşünceler ve Bazı Teklifler, Millî Folklor, 11(41): 61-65.

Özdemir, M. (2020). Giresun Kültürüne Özgü Bir Halk Dansı: “Çandır Tüfek Oyunu”, Gazi Türkiyat, Bahar 2020/26, 145-163.

Serbest, K. (2020). Nevşehir Yöresi Geleneksel Eğlence Unsurlarının Turizmde Kullanımı, Motif Akademi Halk Bilimi Dergisi, 13(30): 745-761. 
Sümbül, M. (1995). Adana Halk Oyunlarının Sistematik Analizi, Yayımlanmamış Yüksek Lisans Tezi, Ankara Üniversitesi Sosyal Bilimler Enstitüsü Halk Bilimi Anabilim Dalı, Ankara.

Sümbül, M. (1997). Halk Oyunlarını İşlevleri, Folklor ve Edebiyat Etnoloji Halkbilim Antropoloji, (11). [Online] http://turkoloji.cu.edu.tr/HALKBILIM/muzaffer_sumbul_halk_oyunlarinin_ islevleri.pdf [Erişim Tarihi: 05.02.2021].

Şahin, M. (2009). Türk Halk Oyunları Türlerine Göre Asma Davulun İncelenmesi, Sanatta Yeterlilik Tezi, İstanbul Teknik Üniversitesi Sosyal Bilimler Enstitüsü, İstanbul.

T.C. Kültür ve Turizm Bakanlığ1 (2019a). Halk Oyunlar. [Online] http://ekitap.kulturturizm.gov.tr/TR-78925/balikesir-oyunlari.html [Erişim Tarihi: 24.04.2019].

T.C. Kültür ve Turizm Bakanlığı (2019b). Pamukçu Bengesi. [Online] http://ekitap.kulturturizm.gov.tr/TR-79585/pamukcu-bengesi.html [Erişim: 24.04.2019].

T.C. Kültür ve Turizm Bakanlığı (2019c). Somut Olmayan Kültürel Miras Unsur Listesi. [Online] http://www.balikesirkulturturizm.gov.tr/TR-131336/somut-olmayan-kulturel-miras-unsurlistesi.html [Erişim Tarihi: 25.04.2019].

T.C. Kültür ve Turizm Bakanlığ1 (2019d). Somut olmayan kültürel miras ne demektir? [Online] http://www.kulturvarliklari.gov.tr/TR-132353/somut-olmayan-kulturel-miras-ne-demektir.html [Erişim Tarihi: 25.04.2019].

Ulusoy Yıldırım, H., Kılıç, S. N. ve Avcıkurt, C. (2020). Antandros Antik Kenti'nin Kültür Turizmine Kazandırılması: Nitel Bir Araştırma, Türk Turizm Araştırmaları Dergisi, 4(3): 1689-1706.

Uslu, M. (2013). Halk Oyunları Çalışmalarının Üniversite Öğrencilerinin Psiko- Sosyal Gelişimlerine Etkisi, Akademik Bakış Dergisi, (39): 1-15.

Yıldırım, A. ve Şimşek, H. (2011). Sosyal Bilimlerde Nitel Araştırma Yöntemleri. (8. Tıpkı Basım), Ankara: Seçkin Yayıncılık.

Yıldırım, A. ve Şimşek, H. (2016). Sosyal Bilimlerde Nitel Araştırma Yöntemleri. (10. Genişletişmiş Baskl), Ankara: Seçkin Yayıncilık.

Yılmaz, G. (2017). Gastronomi ve Turizm İlişkisi Üzerine Bir Değerlendirme, Seyahat ve Otel İşletmeciliği Dergisi, 14(2): 171-191.

Yılmaz, G. ve Özdemir, B. (2017). Turizm Destinasyonlarında Restoran Biçimleşmeleri: Kapadokya Bölgesi Üzerine Nitel Bir Araştırma, Anatolia: Turizm Araştırmaları Dergisi, 28(1): 8195.

Yılmaz, G., Erdem, Ö. ve Arman, A. (2018). Şef Adaylarının Niteliklerine İlişkin Mutfak Şeflerinin Görüşleri, Journal of Tourism and Gastronomy Studies, 6(3): 273-294.

Yin, R. K. (2017). Durum Çalışması Araştırması Uygulamaları (3. Basımdan Çeviri, Çeviren: Günbayı, İ.), Nobel.

Yüksel, G. (2010). Karadeniz'de Bir Zeybek Oyunu: Sepetçioğlu, Uluslararası İnsan Bilimleri Dergisi, 7(2): 1085-1095. 